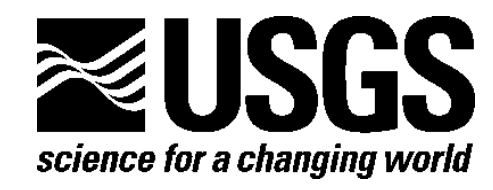

\title{
Geochemical and Stable Isotopic Data on Barren and Mineralized Drill Core in the Devonian Popovich Formation, Screamer Sector of the Betze-Post Gold Deposit, Northern Carlin Trend, Nevada
}

By William D. Christiansen, ${ }^{1}$ Albert H. Hofstra, ${ }^{1}$ Pamela B. Zohar, ${ }^{2}$ and Gilles Tousignant ${ }^{2}$

${ }^{1}$ U.S. Geological Survey, MS-973, Box 25046, Denver, CO 80225

${ }^{2}$ Barrick Goldstrike Mines Inc., Elko, NV 89801

Open-File Report 2010-1077

U.S. Department of the Interior

U.S. Geological Survey 


\section{U.S. Department of the Interior \\ KEN SALAZAR, Secretary}

\section{U.S. Geological Survey \\ Marcia K. McNutt, Director}

U.S. Geological Survey, Reston, Virginia 2011

For product and ordering information:

World Wide Web: http://www.usgs.gov/pubprod

Telephone: 1-888-ASK-USGS

For more information on the USGS-the Federal source for science about the Earth,

its natural and living resources, natural hazards, and the environment:

World Wide Web: http://www.usgs.gov

Telephone: 1-888-ASK-USGS

Suggested citation:

Christiansen, William N., Hofstra, Albert H., Zohar, Pamela B., and Tousignant, Gilles, 2011, Geochemical and stable isotopic data on barren and mineralized drill core in the Devonian Popovich Formation, Screamer sector of the Betze-Post gold deposit, northern Carlin trend, Nevada: U.S. Geological Survey Open-File Report 2010-1077, $11 \mathrm{p}$.

Any use of trade, product, or firm names is for descriptive purposes only and does not imply endorsement by the U.S. Government.

Although this report is in the public domain, permission must be secured from the individual copyright owners to reproduce any copyrighted material contained within this report. 


\section{Contents}

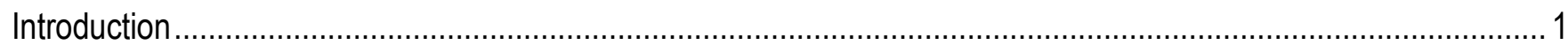

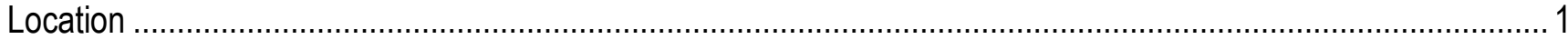

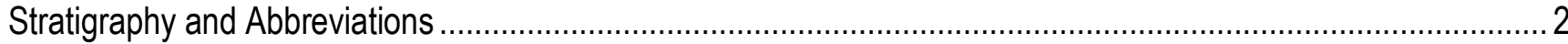

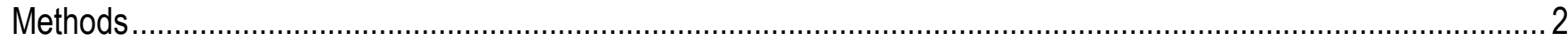

Drill Core, Gold, Sulfur, Carbonate, and Carbonaceous Material Analyses ........................................................ 2

EDS - XRF Antimony and Barium Analyses....................................................................................... 3

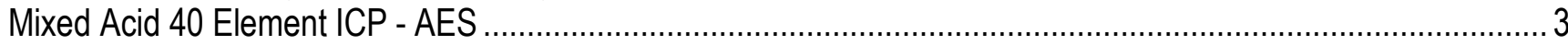

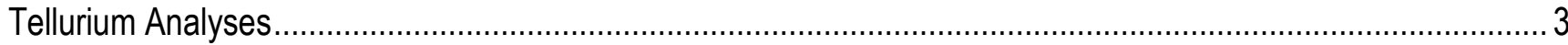

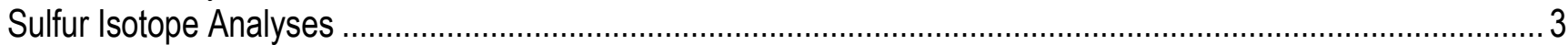

Carbonate Carbon, and Oxygen Isotope Analyses ……………............................................................. 4

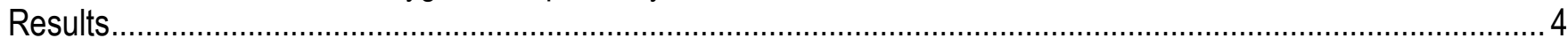

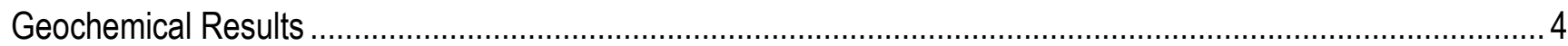

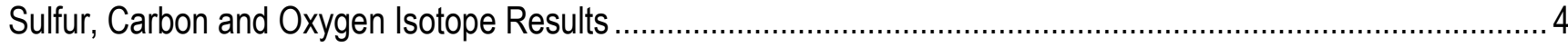

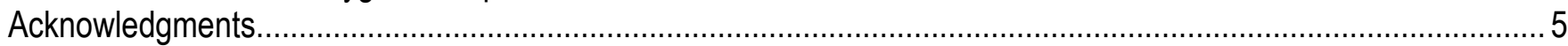

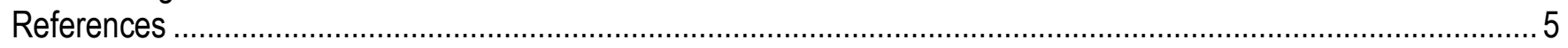

\section{Figures}

1. Location map with mines and general geologic units and structures ........................................................ 6

2. Stratigraphic column with unit descriptions for the Goldstrike property ....................................................... 7

\section{Tables}

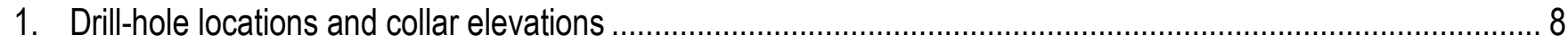

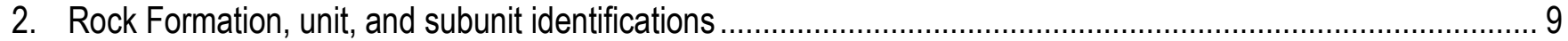

3. Screamer geochemical and isotopic data................................................................................... link 


\title{
Geochemical and Stable Isotopic Data on Barren and Mineralized Drill Core in the Devonian Popovich Formation, Screamer Sector of the Betze-Post Gold Deposit, Northern Carlin Trend, Nevada
}

\author{
By William D. Christiansen, ${ }^{1}$ Albert H. Hofstra, ${ }^{1}$ Pamela B. Zohar, ${ }^{2}$ and Gilles Tousignant ${ }^{2}$
}

${ }^{1}$ U.S. Geological Survey, MS-973, Box 25046, Denver, CO 80225

${ }^{2}$ Barrick Goldstrike Mines Inc., Elko, NV 89801

\section{Introduction}

The Devonian Popovich Formation is the major host for Carlin-type gold deposits in the northern Carlin trend of Nevada. The Popovich is composed of gray to black, thin-bedded, calcareous to dolomitic mudstone and limestone deposited near the carbonate platform margin. Carlin-type gold deposits are Eocene, disseminated, auriferous pyrite deposits characterized by acid leaching, sulfidation, and silicification that are typically hosted in Paleozoic calcareous sedimentary rocks exposed in windows through siliceous sedimentary rocks of the Roberts Mountains allochthon (Hofstra and Cline, 2000). The Carlin trend currently is the largest gold producer in the United States. The Screamer ore zone is a tabular body on the periphery of the huge Betze-Post gold deposit. Screamer is a good place to study both the original lithogeochemistry of the Popovich Formation and the effects of subsequent alteration and mineralization because it is below the level of supergene oxidation, mostly outside the contact metamorphic aureole of the Jurassic Goldstrike stock (fig. 1), has small, high-grade ore zones along fractures and Jurassic dikes, and has intervening areas with lower grade mineralization and barren rock (Hofstra and others, 2011). In 1997, prior to mining at Screamer, drill core intervals from barren and mineralized Popovich Formation were selected for geochemical and stable isotope analysis. The 332 , five-foot core samples analyzed are from five holes separated by as much as 2000 feet (600 meters). The samples extend from the base of the Wispy unit up through the Planar and Soft sediment deformation units into the lower part of the upper Mud unit of the Popovich Formation. The purpose of this report is to present the analytical methods and results. It is the basis for a companion report whose purpose is to interpret the data and to characterize the original geochemical and isotopic composition of the Popovich Formation and subsequent changes due to hydrothermal activity (Hofstra and others, 2011).

\section{Location}

Screamer is on the northwestern periphery of the Betze-Post gold deposit in the northern Carlin trend (fig. 1). It is located in Eureka County, Nevada, on the Rodeo Creek NW 7.5 minute quadrangle. Table 1 lists drill-hole coordinates and elevations. 


\section{Stratigraphy and Abbreviations}

Figure 2 portrays the stratigraphy at the Barrick Goldstrike mine. Table 2 shows the formation, unit (informal member in fig. 2), and subunit picks for the sampled drill holes. Jurassic dikes (Ji) are divided into the following units: diorite (JDI), monzonite porphyry (JMP), lamprophyre (JLA), and biotitic lamprophyre (JBLA). Units of the Devonian Popovich Formation (DP) are abbreviated as follows: Wispy (WS), Planar (PL), Soft sediment deformation (SD), and upper Mud (UM). The Wispy unit is divided into a lower wispy subunit (WSS) and an upper wispy planar subunit (WSPL). The Planar (PL) and Soft sediment deformation (SD) units are not divided into smaller subunits, but are given the following subunit designations PLS and SDS, respectively. The upper Mud unit (UM) is divided into four subunits from bottom to top as follows: upper mud subunit (UMS), cherty lens subunit (CTL), pinstripe pyrite subunit (PIN), and the thin on thin subunit (TOT).

\section{Methods}

\section{Drill Core, Gold, Sulfur, Carbonate, and Carbonaceous Material Analyses}

Vertically oriented exploratory rock core holes were drilled, logged, photographed, and assayed for gold, sulfur, carbonate, and carbonaceous material by Barrick Gold Corporation in 1997. Five-foot core intervals were split, ground to -200 mesh (74 microns) pulps, and analyzed for gold by Barrick using in-house fire assay (FA), and atomic absorption (AA) methods. Barrick in-house LECO combustion methods were used to determine sulfur, carbonate $\left(\mathrm{CO}_{3},\right)$ and total carbonaceous matters (TCM). Pulp splits were analyzed for major, minor, and trace elements and sulfur, carbonate carbon and carbonate oxygen isotopes by the U.S. Geological Survey (USGS) between 1998 and 2007.

The fire assay gold method consists of heating an aliquot (10 to 50 grams) of the finely pulverized sample mixed with approximately three parts of a flux until the product is molten. Lead oxide in the flux is reduced to metallic lead by other constituents of the flux or the sample. The metallic lead amalgamates with the gold, silver, and small quantities of certain base metals present in the sample and falls to the bottom of the crucible to form a lead button. The bulk of the sample is converted by the flux into a glassy fluid that allows the particles of lead to fall through the molten mass. The lead button is cupelled to oxidize the lead, leaving behind a dore bead containing the precious metals.

The dore bead is transferred to a test tube, dissolved with aqua regia, diluted to a specific volume, and quantified by atomic absorption (AA) spectrophotometry. AA is a method that determines gold concentration by introducing the gold in aqua regia solution to a light beam of appropriate wavelength, causing gold atoms to absorb light. The reduction in the intensity of the light beam directly correlates with the concentration of the gold. The lower reporting level for atomic absorption was 0.001 ounce per ton gold (oz/ton $\mathrm{Au}$ ). The upper reporting limit for AA was $0.2 \mathrm{oz} /$ ton $\mathrm{Au}$.

If gold is greater than $0.2 \mathrm{oz} / \mathrm{ton}$, then a gravimetric method is used. The dore bead is instead treated with dilute nitric acid to quantitatively remove the silver. The residual mass of pure gold is then weighed and its concentration in the sample calculated. There is no upper quantitative limit to the gravimetric method.

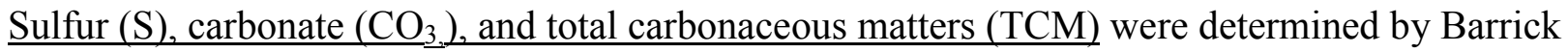
in-house LECO combustion methods. Carbonate was determined by weight percent loss during a hydrochloric acid digestion. Carbonaceous matters in the remaining portion of the sample were oxidized to carbon dioxide $\left(\mathrm{CO}_{2}\right)$ and sulfur was converted to sulfur dioxide $\left(\mathrm{SO}_{2}\right)$ in an induction furnace. Carbon dioxide $\left(\mathrm{CO}_{2}\right)$ and $\mathrm{SO}_{2}$ were then measured by infrared (IR) detectors. The level of accuracy 
and precision is approximately 1 percent. For additional information, see Brown and Curry (2002a and 2002b).

\section{EDS - XRF Antimony and Barium Analyses}

Antimony $(\mathrm{Sb})$ and barium $(\mathrm{Ba})$ were analyzed using a Kevex energy-dispersive X-ray spectrometer, interfaced to an analyzer at the USGS in Denver, Colorado. Primary excitation was supplied by an americium source. A gadolinium secondary target excited the K-alpha lines of antimony and barium. The fluoresced X-rays were detected using a Kevex energy-dispersive detector equipped with a beryllium window, and a Kevex pulse processor. Counting time was 100 seconds live time on loose powder splits of the pulped Screamer core. For a full discussion of the EDS - XRF technique see Ahmedali (1989). Lower reporting limits for both antimony and barium were $10 \mathrm{ppm}$. Upper reporting limits for both antimony and barium were somewhat greater than 50 percent. Estimated precision or reproducibility was 5 to 10 percent of the amount present (at $100 \mathrm{ppm}$ ) based repeated analyses of several USGS in-house standards (G.A. Desborough, written commun., 2006).

\section{Mixed Acid 40 Element ICP - AES}

Splits of the pulped Screamer core were analyzed for 40 major, minor, and trace elements by inductively coupled plasma - atomic emission spectrometry (ICP - AES) at XRAL, a contract laboratory for the USGS. Unused splits of the sample pulps are archived in Building 810 at the Denver Federal Center. Sample aliquots of 200 milligrams were decomposed using a mixture of hydrochloric, nitric, perchloric, and hydrofluoric acids at $150^{\circ} \mathrm{C}$. The digested samples were aspirated into the ICP - AES discharge where the elemental emission signal was measured simultaneously for the 40 elements. Calibration was performed using with a series of multielement solution standards.

Data were deemed acceptable if recovery for all 40 elements was \pm 15 percent at five times the Lower Limit of Determination (LOD) and the calculated Relative Standard Deviation (RSD) of duplicate samples was no greater than 15 percent. For additional information, see Briggs (1996, 2002).

\section{Tellurium Analyses}

Tellurium was analyzed by XRAL laboratories (under USGS contract) using a separate split of the core pulps. Tellurium was determined by weighing 0.25 gram of sample into a Teflon tube, adding a mixture of nitric, hydrofluoric, and perchloric acids, and heating. After the solution cooled, hydrochloric and nitric acids were added, the solution heated again, and cooled. The samples were diluted and analyzed using hydride-generation atomic absorption spectrometry (HGAAS) with an automatic analyzer and automated data-collection system. The lower reporting limit for tellurium was $0.1 \mathrm{ppm}$.

Data for tellurium were deemed acceptable if recovery of that element was \pm 20 percent at five times the LOD and the calculated percent RSD of duplicate samples was no greater than 20 percent. For additional information, see O’Leary (1996).

\section{Sulfur Isotope Analyses}

Sulfur isotope ratio analyses were carried out by a continuous flow method patterned after Giesemann and others (1994) using a Carlo Erba NC2500 elemental analyzer coupled to a Micromass Optima mass spectrometer at the USGS in Denver. Carbonate hydrochloric acid treatment: Samples containing greater than 25 percent carbonate $\left(\mathrm{CO}_{3}\right.$ by LECO analyses) were treated in 5-percent $\mathrm{HCl}$ to remove carbonates. Several milligrams of sample pulps were immersed in 5-percent $\mathrm{HCl}$ solution at 
room temperature for 12 hours. The pulps were filtered and rinsed in DI water using a Millipore 0.45micrometer vacuum filter and air-dried.

The sample pulps (acid treated and untreated) were weighed in amounts corresponding to 0.1 milligram sulfur (3.1 micromoles sulfur) based on LECO sulfur concentration measurements and were wrapped together with $\mathrm{V}_{2} \mathrm{O}_{5}$ in tin capsules. Then they were combusted in a furnace held at $1,080^{\circ} \mathrm{C}$ within a 5-milliliter pulse of oxygen in the elemental analyzer. All gases produced during combustion were carried on a stream of helium gas through an oxidation-reduction reactor filled with tungstic anhydride, copper oxide, and reduced copper as recommended by Carlo Erba. Sweeping all gases over heated copper oxide and reduced copper, any sulfur trioxide $\left(\mathrm{SO}_{3}\right)$ produced during combustion was converted to sulfur dioxide $\left(\mathrm{SO}_{2}\right)$ and the surplus of oxygen consumed. Water vapor was removed using a desiccant trap containing $\mathrm{Mg}\left(\mathrm{ClO}_{4}\right)$. Finally, the gases were passed through a Poropak QS column to isolate the $\mathrm{SO}_{2}$.

A portion of the GC column effluent was transferred through a fused silica capillary into the ion source of the mass spectrometer. Reference gas was supplied by injecting a pulse of reagent grade $\mathrm{SO}_{2}$ into the carrier gas between the elemental analyzer and open split interface. The mass spectrometer measurements were made by isotope ratio monitoring methods. Ion currents of mass 64 and 66 were recorded over time the gas spent in the source, and the areas underneath these peaks were integrated. All results are reported in delta notation in per mil relative to Vienna Cañon Diablo Troilite (VCDT).

Sulfur isotope analyses were reproducible to within \pm 0.3 per mil based on repeated analyses of standards NBS - 123 sphalerite and NBS - 127 barium sulfate.

\section{Carbonate Carbon, and Oxygen Isotope Analyses}

Carbonate carbon and oxygen stable isotope analyses were performed at the USGS in Denver. Several milligrams of powdered core from selected 5-foot intervals were digested in phosphoric acid following McCrea (1950). The resulting carbon dioxide gas was purified in a vacuum line using silver phosphate, at $25^{\circ} \mathrm{C}$, to remove any hydrogen sulfide that may have evolved from trace sulfide minerals. The carbon dioxide samples were analyzed for their isotopic compositions by using a Finnigan MAT 252 mass spectrometer. The results are reported in delta notation in units of per mil relative to Vienna Pee Dee Belemnite (VPDB) for carbon and Vienna Standard Mean Ocean Water (VSMOW) for oxygen. The reported values include a correction for oxygen fractionation that was made using the dolomite fractionation factor recommended by Friedman and O'Neil (1977).

Carbonate isotope analyses were reproducible to within \pm 0.1 per mil for carbon and within \pm 0.4 for oxygen based on repeated analyses of standards NBS - 18 (carbonatite) and NBS - 19 (calcite).

\section{Results}

\section{Geochemical Results}

Fire assay - AA, LECO, XRF, HGAAS, and ICP - AES analytical results for each 5-foot interval of drill core are reported in table 3.

\section{Sulfur, Carbon and Oxygen Isotope Results}

The total sulfur and carbonate carbon and oxygen isotope compositions of each 5-foot interval of drill core are reported in table 3.

Interpretation of the geochemical and isotopic results is covered in a separate report by Hofstra and others (2010). 


\section{Acknowledgments}

We thank Barrick Goldstrike Mines Inc. for supplying the pulped drill core, stratigraphic control, drill-hole locations, gold FA/AA, and LECO analyses. At the USGS, we thank Pam Gemery, Cindy Kester, and Carl Bern for the sulfur isotope analyses, Craig Johnson and Bob Rye for important suggestions on isotopic techniques and interpretations, and George Desborough for training on the Kevex XRF. Reviews by Craig Johnson and David Fey improved the manuscript greatly.

\section{References}

Ahmedali, S.T. (Syed Tariq), 1989, X-ray fluorescence analysis in the geological sciences, Advances in methodology: Geological Association of Canada, St. John's, Newfoundland, Short course notes, v. 7 , 297 p.

Bettles, Keith, 2002, Exploration and geology, 1962 to 2002, at the Goldstrike Property, Carlin Trend, Nevada: Special Publication, Society of Economic Geologists, v. 9, p. 275 - 298.

Briggs, P.H., 1996, Forty elements by inductively coupled plasma-atomic emission spectrometry, in Arbogast, B.F., ed., Analytical methods manual for the Mineral Resource Surveys Program: U.S. Geological Survey Open-File Report 96 - 525, p. 77 - 94.

Briggs, P.H., 2002, The determination of forty elements in geological and botanical samples by inductively coupled plasma-atomic emission: U.S. Geological Survey Open-File Report 2002 - 223, p. G1 - G18.

Brown, Z.A., and Curry, K.J., 2002a, Total carbon by combustion: U.S. Geological Survey Open-File Report 2002 - 223, p. R1 - R4.

Brown, Z.A., and Curry, K.J., 2002b, Total sulfur by combustion: U.S. Geological Survey Open-File Report 2002 - 223, p. Q1 - Q4.

Friedman, I., and O'Neil, J.R., 1977, Compilation of stable isotope fractionation factors of geochemical interest: U.S. Geological Survey Professional Paper 440 - KK, 12 p.

Giesemann, A., Jäger, H.J., Norman, A.L., Krouse, H.R., and Brand, W.A., 1994, On-line sulfur-isotope determination using an elemental analyzer coupled to a mass spectrometer: Analytical Chemistry, v. 66, p. $2816-2819$.

Hofstra, A.H., and Cline, J.S., 2000, Characteristics and models for Carlin-type gold deposits, chapter 5, in Hagemann, S.G., and Brown, P.E., eds., Gold in 2000: Reviews in Economic Geology, v. 13, p. $163-220$.

Hofstra, A.H., Christiansen, W.D., Zohar, P.B., and Tousignant, G., 2011, Lithogeochemistry of the Devonian Popovich Formation in the Northern Carlin Trend, Nevada, in Steininger, R. and Pennell, W., eds., Geological Society of Nevada 2010 Symposium: Great Basin Evolution \& Metallogeny, Reno, Nevada, May 2010, p. 63- 97.

McCrea, J.M., 1950, On the isotopic chemistry of carbonates and a paleotemperature scale: Journal of Chemistry and Physics, v. 18, p. 849 - 857.

O'Leary, R.M., 1996, Tellurium and thallium by flame atomic absorption spectrometry, in Arbogast, B.F., ed., Analytical methods manual for the Mineral Resource Surveys Program: U.S. Geological Survey Open-File Report 96 - 525, p. 37 - 41. 


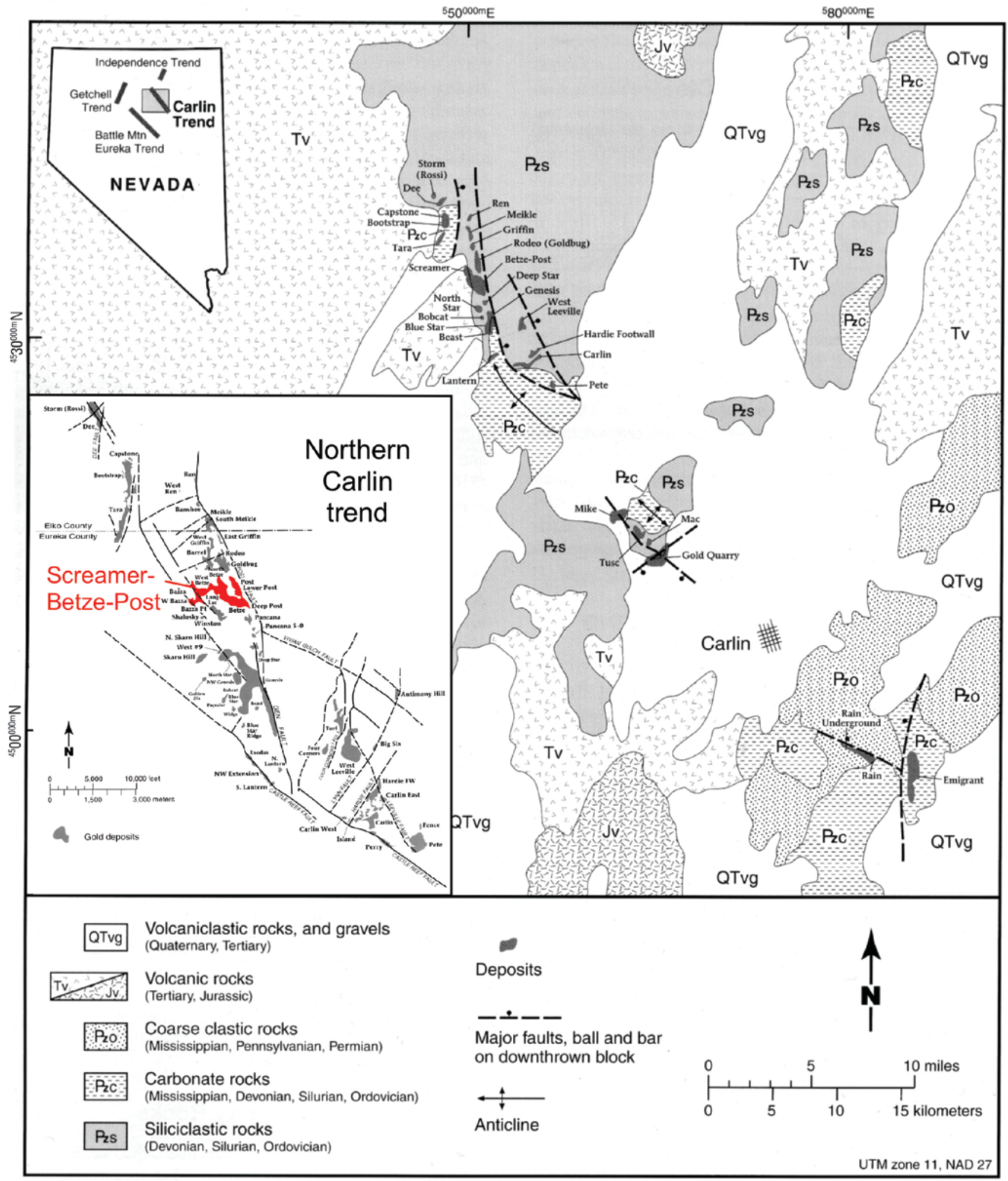

Figure 1. Location map with mines and general geologic units and structures, from Hofstra and others (2010). 


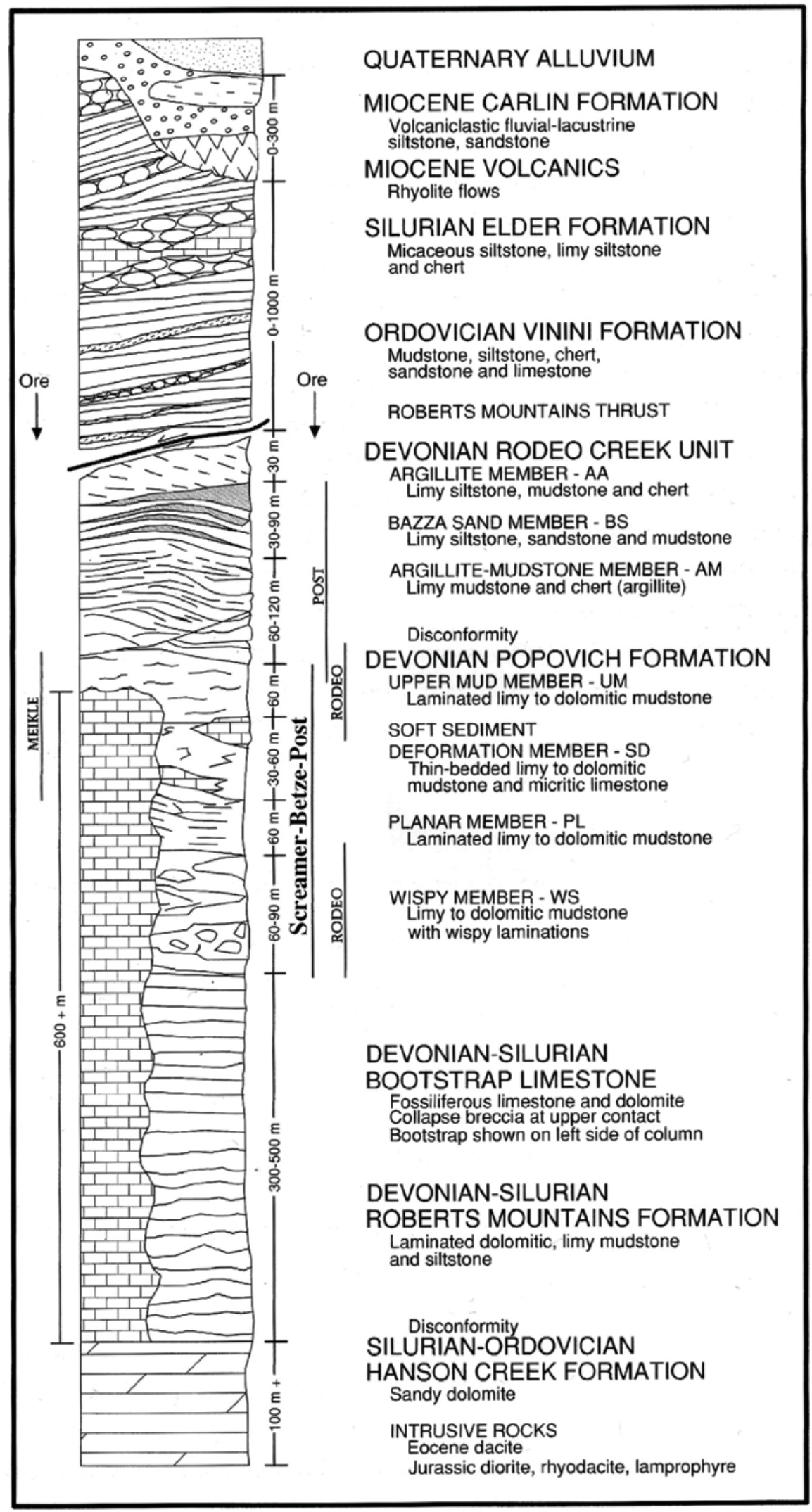

Figure 2. Stratigraphic column with unit descriptions for the Goldstrike property, from Bettles (2002). 
Table 1. Drill-hole locations and collar elevations.

\begin{tabular}{lccccc}
\hline 7.5' quad & Spheroid & Datum & & & \\
\hline Rodeo Creek NW & $\begin{array}{l}\text { Clarke } \\
1866\end{array}$ & NAD27 & & & \\
\hline & $\begin{array}{c}\text { Barrick } \\
\text { grid } \\
\text { northing } \\
\text { (feet) }\end{array}$ & $\begin{array}{c}\text { Barrick } \\
\text { grid } \\
\text { easting } \\
\text { (feet) }\end{array}$ & $\begin{array}{c}\text { Collar } \\
\text { elevation } \\
\text { (feet) }\end{array}$ & Latitude & Longitude \\
Core hole number & $13,478.60$ & $7,433.20$ & $5,467.20$ & 40.9878 & -116.3841 \\
SJ-513C & $12,679.20$ & $5,822.90$ & $5,360.60$ & 40.9870 & -116.3942 \\
SJ-497C & $12,910.30$ & $6,105.40$ & $5,359.30$ & 40.9871 & -116.3923 \\
SJ-477C & $12,139.90$ & $7,115.10$ & $5,490.70$ & 40.9867 & -116.3881 \\
SJ-448C & $11,406.40$ & $6,528.10$ & $5,460.10$ & 40.9863 & -116.3911 \\
BZ-954C & & & & & \\
\hline
\end{tabular}


Table 2. Rock Formation, unit, and subunit identifications.

\begin{tabular}{|c|c|c|c|c|c|}
\hline \multirow[b]{2}{*}{ Drill hole } & \multicolumn{3}{|c|}{ Depth interval in feet } & \multirow[b]{2}{*}{ unit } & \multirow[b]{2}{*}{ subunit } \\
\hline & From & To & Formation & & \\
\hline SJ-513C & 0.0 & 20.0 & $\mathrm{TC}$ & (Miocene Carlin Formation) & \\
\hline SJ-513C & 20.0 & 210.0 & $\mathrm{OV}$ & (Ordovician Vinini Formation) & \\
\hline SJ-513C & 210.0 & 680.0 & DRC & (Devonian Rodeo Creek Unit) & \\
\hline SJ-513C & 680.0 & 700.0 & DP & UM & TOT \\
\hline SJ-513C & 700.0 & 720.0 & DP & UM & PIN \\
\hline SJ-513C & 720.0 & 760.0 & DP & UM & CTL \\
\hline SJ-513C & 760.0 & 800.0 & DP & UM & UMS \\
\hline SJ-513C & 800.0 & 895.0 & DP & SD & SDS \\
\hline SJ-513C & 895.0 & 896.0 & (Ji) & JDI & \\
\hline SJ-513C & 896.0 & 985.0 & DP & SD & SDS \\
\hline SJ-513C & 985.0 & $1,063.0$ & DP & PL & PLS \\
\hline SJ-513C & $1,063.0$ & $1,122.0$ & DP & WS & WSPL \\
\hline SJ-513C & $1,122.0$ & $1,277.0$ & DP & WS & WSS \\
\hline SJ-513C & $1,277.0$ & $1,327.3$ & SDRM & (D-S Roberts Mountain Fm.) & \\
\hline SJ-477C & 0.0 & 70.0 & $\mathrm{TC}$ & (Miocene Carlin Formation) & \\
\hline SJ-477C & 70.0 & 80.0 & OV & (Ordovician Vinini Formation) & \\
\hline SJ-477C & 80.0 & 490.0 & DRC & (Devonian Rodeo Creek Unit) & \\
\hline SJ-477C & 490.0 & 560.0 & DP & UM & PIN \\
\hline SJ-477C & 560.0 & 595.0 & DP & UM & CTL \\
\hline SJ-477C & 595.0 & 635.0 & DP & UM & UMS \\
\hline SJ-477C & 635.0 & 754.6 & DP & SD & SDS \\
\hline SJ-477C & 754.6 & 781.0 & $(\mathrm{Ji})$ & JBLA & \\
\hline SJ-477C & 781.0 & 839.5 & DP & SD & SDS \\
\hline SJ-477C & 839.5 & 935.0 & DP & PL & PLS \\
\hline SJ-477C & 935.0 & 988.0 & DP & WS & WSPL \\
\hline SJ-477C & 988.0 & $1,068.0$ & DP & WS & WSS \\
\hline SJ-477C & $1,068.0$ & $1,264.0$ & VDF & Void/cavity & \\
\hline
\end{tabular}

Formation and unit abbreviations are derived from rock units in Figure 2.

See text for Popovich Formation subunit and Jurasic dike abbreviations. 
Table 2. Rock Formation, unit, and subunit identifications.-Continued

\begin{tabular}{|c|c|c|c|c|c|}
\hline \multirow[b]{2}{*}{ Drill Hole } & \multicolumn{3}{|c|}{ Depth interval in feet } & \multirow[b]{2}{*}{ unit } & \multirow[b]{2}{*}{ subunit } \\
\hline & From & To & Formation & & \\
\hline SJ-497C & 0.0 & 115.0 & $\mathrm{TC}$ & (Miocene Carlin Formation) & \\
\hline SJ-497C & 115.0 & 310.0 & DRC & (Devonian Rodeo Creek Unit) & \\
\hline SJ-497C & 310.0 & 311.0 & UDK & Unidentified dike & \\
\hline SJ-497C & 311.0 & 342.0 & $\mathrm{DRC}$ & (Devonian Rodeo Creek Unit) & \\
\hline SJ-497C & 342.0 & 351.0 & (Ji) & JDI & \\
\hline SJ-497C & 351.0 & 405.0 & DRC & (Devonian Rodeo Creek Unit) & \\
\hline SJ-497C & 405.0 & 415.0 & (Ji) & JLA & \\
\hline SJ-497C & 415.0 & 555.0 & DRC & (Devonian Rodeo Creek Unit) & \\
\hline SJ-497C & 555.0 & 590.0 & DP & UM & PIN \\
\hline SJ-497C & 590.0 & 630.0 & DP & UM & CTL \\
\hline SJ-497C & 630.0 & 680.0 & DP & UM & UMS \\
\hline SJ-497C & 680.0 & 790.0 & DP & SD & SDS \\
\hline SJ-497C & 790.0 & 795.0 & NS & No Sample & \\
\hline SJ-497C & 795.0 & 816.0 & DP & $\mathrm{SD}$ & SDS \\
\hline SJ-497C & 816.0 & 908.0 & DP & PL & PLS \\
\hline SJ-497C & 908.0 & 910.0 & (Ji) & JDI & \\
\hline SJ-497C & 910.0 & 942.0 & DP & PL & PLS \\
\hline SJ-497C & 942.0 & 996.0 & DP & WS & WSPL \\
\hline SJ-497C & 996.0 & 998.0 & (Ji) & JMP & \\
\hline SJ-497C & 998.0 & 999.0 & DP & WS & WSPL \\
\hline SJ-497C & 999.0 & $1,001.5$ & $(\mathrm{Ji})$ & JMP & \\
\hline SJ-497C & $1,001.5$ & $1,007.0$ & DP & WS & WSS \\
\hline SJ-497C & $1,007.0$ & $1,012.2$ & (Ji) & JMP & \\
\hline SJ-497C & $1,012.2$ & $1,193.0$ & DP & WS & WSS \\
\hline SJ-497C & $1,193.0$ & $1,331.5$ & SDRM & (D-S Roberts Mountain Fm.) & \\
\hline SJ-497C & $1,331.5$ & $1,332.2$ & $(\mathrm{Ji})$ & JLA & \\
\hline SJ-497C & $1,332.2$ & $1,372.3$ & SDRM & (D-S Roberts Mountain Fm.) & \\
\hline BZ-954C & 0.0 & 20.0 & $\mathrm{TC}$ & (Miocene Carlin Formation) & \\
\hline BZ-954C & 20.0 & 364.0 & DRC & (Devonian Rodeo Creek Unit) & \\
\hline BZ-954C & 364.0 & 366.0 & $(\mathrm{Ji})$ & JLA & \\
\hline BZ-954C & 366.0 & 490.0 & DRC & (Devonian Rodeo Creek Unit) & \\
\hline BZ-954C & 490.0 & 505.0 & TBFP? & Tert. Dacite porphyry? & \\
\hline BZ-954C & 505.0 & 515.0 & (Ji) & JLA & \\
\hline BZ-954C & 515.0 & 565.0 & DP & $\mathrm{UM}$ & UMS \\
\hline BZ-954C & 565.0 & 572.0 & (Ji) & JLA? & \\
\hline BZ-954C & 572.0 & 730.0 & DRC & (Devonian Rodeo Creek Unit) & \\
\hline BZ-954C & 730.0 & 840.0 & DP & UM & UMS \\
\hline BZ-954C & 840.0 & 935.0 & DP & SD & SDS \\
\hline BZ-954C & 935.0 & $1,014.0$ & DP & PL & PLS \\
\hline BZ-954C & $1,014.0$ & $1,069.0$ & DP & WS & WSPL \\
\hline BZ-954C & $1,069.0$ & $1,320.0$ & DP & WS & WSS \\
\hline BZ-954C & $1,320.0$ & $1,388.0$ & SDRM & (D-S Roberts Mountain Fm.) & \\
\hline BZ-954C & $1,388.0$ & $1,400.0$ & UDK & Unidentified dike & \\
\hline BZ-954C & $1,400.0$ & $1,407.0$ & $\mathrm{BXF}$ & Breccia SDRM \& UDK & \\
\hline BZ-954C & $1,407.0$ & $1,486.0$ & SDRM & (D-S Roberts Mountain Fm.) & \\
\hline
\end{tabular}

Formation and unit abbreviations are derived from rock units in Figure 2.

See text for Popovich Formation subunit and Jurasic dike abbreviations. 
Table 2. Rock Formation, unit, and subunit identifications - Continued

\begin{tabular}{|c|c|c|c|c|c|}
\hline \multirow[b]{2}{*}{ Drill Hole } & \multicolumn{3}{|c|}{ Depth interval in feet } & \multirow[b]{2}{*}{ unit } & \multirow[b]{2}{*}{ subunit } \\
\hline & From & To & Formation & & \\
\hline SJ-448C & 0.0 & 20.0 & TC & & \\
\hline SJ-448C & 20.0 & 60.0 & $\mathrm{OV}$ & (Ordovician Vinini Formation) & \\
\hline SJ-448C & 60.0 & 75.0 & UDK & Unidentified dike & \\
\hline SJ-448C & 75.0 & 140.0 & $\mathrm{OV}$ & (Ordovician Vinini Formation) & \\
\hline SJ-448C & 140.0 & 205.0 & DRC & (Devonian Rodeo Creek Unit) & \\
\hline SJ-448C & 205.0 & 207.0 & $(\mathrm{Ji})$ & JDI & \\
\hline SJ-448C & 207.0 & 468.0 & DRC & (Devonian Rodeo Creek Unit) & \\
\hline SJ-448C & 468.0 & 485.0 & (Ji) & JMP & \\
\hline SJ-448C & 485.0 & 535.0 & DRC & (Devonian Rodeo Creek Unit) & \\
\hline SJ-448C & 535.0 & 536.0 & $(\mathrm{Ji})$ & JMP & \\
\hline SJ-448C & 536.0 & 550.0 & DRC & (Devonian Rodeo Creek Unit) & \\
\hline SJ-448C & 550.0 & 560.0 & DP & UM & PIN \\
\hline SJ-448C & 560.0 & 620.0 & DP & UM & CTL \\
\hline SJ-448C & 620.0 & 660.0 & DP & UM & UMS \\
\hline SJ-448C & 660.0 & 899.0 & DP & SD & SDS \\
\hline SJ-448C & 899.0 & 992.0 & DP & PL & PLS \\
\hline SJ-448C & 992.0 & $1,029.0$ & DP & WS & WSPL \\
\hline SJ-448C & $1,029.0$ & $1,042.4$ & DP & WS & WSS \\
\hline SJ-448C & $1,042.4$ & $1,051.9$ & $(\mathrm{Ji})$ & JLA & \\
\hline $\mathrm{SJ}-448 \mathrm{C}$ & $1,051.9$ & $1,248.0$ & DP & WS & WSS \\
\hline SJ-448C & $1,248.0$ & $1,290.0$ & SDRM & (D-S Roberts Mountain Fm.) & \\
\hline
\end{tabular}

Formation and unit abbreviations are derived from rock units in Figure 2.

See text for Popovich Formation subunit and Jurasic dike abbreviations. 